OUTLAW JUSTICE 



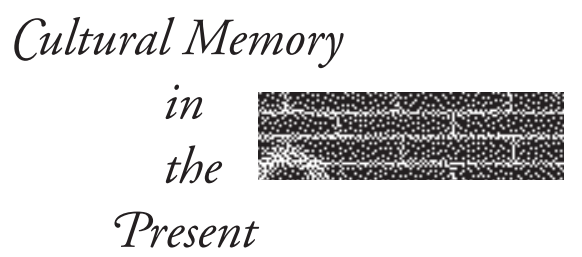

Hent de Vries, Editor 



\section{OUTLAW JUSTICE}

The Messianic Politics of Paul

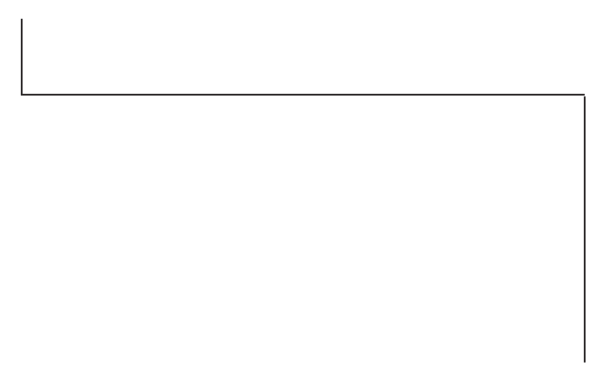

Theodore W. Jennings, Jr. 
Stanford University Press

Stanford, California

(C) 2013 by the Board of Trustees of the Leland Stanford Junior University. All rights reserved.

No part of this book may be reproduced or transmitted in any form or by any means, electronic or mechanical, including photocopying and recording, or in any information storage or retrieval system without the prior written permission of Stanford University Press.

Printed in the United States of America on acid-free, archival-quality paper

Library of Congress Cataloging-in-Publication Data

Jennings, Theodore W., author.

Outlaw justice : the Messianic politics of Paul / Theodore W. Jennings, Jr. pages $\mathrm{cm}$. - (Cultural memory in the present)

Includes bibliographical references and index.

ISBN 978-0-8047-8516-7 (cloth : alk. paper)

ISBN 978-0-8047-8517-4 (pbk. : alk. paper)

I. Bible. N.T. Romans-Philosophy. 2. Paul, the Apostle, Saint-Political and social views. 3. Justice-Biblical teaching. 4. Justice (Philosophy) I. Title.

II. Series: Cultural memory in the present.

$\mathrm{BS}_{2665.6 . J 8 J 456 \quad 2013}$

$227^{\prime} .106-\mathrm{dc} 23$

2012033120

ISBN 978-0-8047-8599-o (electronic) 